\title{
The European Universities Initiative: A Study of Alliance Formation in Higher Education
}

\author{
Andrew Gunn
}

\section{Collaboration in Higher Education}

\begin{abstract}
Alliances are a longstanding feature of the higher education landscape. The Universities Bureau of the British Empire represents an early example which was founded in 1913 and would later become the Association of Commonwealth Universities that is still in operation today (Pietsch 2013). Another important milestone in the development of global alliances includes the International Association of Universities, which was first proposed in 1948 by the government of the Netherlands and the United Nations Educational, Scientific and Cultural Organization and launched in 1950. Moodie (2010) notes that the "number of international associations of universities has exploded since the 1970s. In the 35 years from 1972 to 2007 at least 38 international associations of universities were established, more than one each year. Neither is the pace slackening."

Alliances take many forms and operate at different territorial scales. To help classify the myriad of different manifestations of cooperation in higher education, Beerkens (2002) uses concepts from organisational and management studies to develop a multidimensional typology of international inter-organisational cooperation. The critical dimensions within the typology are size, scope, nature of integration and intensity. Tadaki and Tremewan (2013) observe how the internationalisation strategies of universities increasingly feature activities of engagements with and through international consortia which they see as a "new set of actors, logics and relations between and beyond institutions of higher education and research" ( $\mathrm{p}$. 367). We can position the EUI initiative as a new regional scheme within this context of heightened collaboration.
\end{abstract}

\footnotetext{
A. Gunn (ه)

University of Leeds, Leeds, United Kingdom

e-mail: a.s.gunn@education.leeds.ac.uk

(C) The Author(s) 2020

A. Curaj et al. (eds.), European Higher Education Area: Challenges for a New Decade, https://doi.org/10.1007/978-3-030-56316-5_2
} 


\section{The Idea of a European University}

The idea of a supranational university is as old as the European political project. ${ }^{1} \mathrm{~A}$ European university was first mooted in 1948 by German economist Alfred MüllerArmack who believed European integration would require 'a community of the intelligence' in order to be completed. Here, a supranational university would help to fulfil this requirement while also acting as a 'role model' institution (Lehmann 2019, p. 77). The idea was later taken forward by German academic and diplomat Walter Hallstein in 1955, when he was the representative of Germany at a meeting of the original six members of the European Coal and Steel Community (SCSC) in Sicily (Küsters 1998). The German ${ }^{2}$ delegation produced a paper for the summit on European integration which set out how their government "hopes to show tangible testimony to young people of the desire for European Union through the foundation of a European University to be created by the six SCSC states" (cited in Corbett 2005 p. 26). In presenting the paper, Hallstein argued that the view in Bonn was that integration ought not to be solely about the economic domain but should also involve some sort of cultural integration (Corbett 2005 p. 26). This point identifies what would be an enduring fault line running through the European political project: is it about economics and trade or culture and social solidarity, or both? And where does higher education fit into both of these differing rationales?

Müller-Armack and Hallstein continued to pursue what was now the German position, where a European University would be an 'intellectual homeland' that contributed to cultural integration and nurtured a European elite (Corbett 2005, p.38). Although not opposed to the idea, European leaders, faced with the pressing problems of immediate post-war Europe, didn't see a new university as being their number one priority. Yet, the issue was significant enough to remain on the agenda and was taken up by France. However, the French position differed from the German one, and the disagreement over the supranational university would be an early example of how the Franco-German relationship would be prominent in determining the dynamics of integration (Cole 2010; Webber 2005; Hendriks and Morgan 2001). The French saw the value of a European university solely in the then-emerging area of nuclear energy research and training, so placed the proposed university within the Euratom ${ }^{3}$ Treaty, not the European Economic Community (EEC) Treaty which concerned economic and political union, thus blocking the German vision for a supranational university (Corbett 2012, p. 45).

This juncture had consequences for the European University, as Orr et al. (2019) explain, whereby it became untethered from the broader work of the community "and was instead linked primarily to innovation and development rather than European

\footnotetext{
${ }^{1}$ This history of this debate from the late 1940s onwards has been well documented by Palayret (1996), Corbett (2005) and Lehmann (2019).

${ }^{2}$ Federal Republic of Germany, Bundesrepublik Deutschland.

${ }^{3}$ The European Atomic Energy Community (Euratom) Treaty was signed the same time as the European Economic Community Treaty, 25th March 1957, but is a distinct document concerned with nuclear power.
} 
cultural integration. This tension, between a Europe united through culture and a Europe united in development, has followed the university project ever since."

The university included in the Euratom Treaty was never realised (Corbett 2012, p. 35). Discussions continued throughout the 1950s but remained gridlocked owing to a lack of consensus over its legal and financial status, if it would be a nation state competency, where it should be built/based and whether it should be a comprehensive or specialist institution. Another critical dimension which hampered the creation of a supranational university was the strong opposition from existing universities. Lehmann (2019) argues that "university representatives were decisive informal actors, influencing the formal negotiations", and that a European University was "first and foremost rejected due to academic resistance which especially heads of universities from western continental European countries organised in the late 1950s" (p. 76).

Despite the opposition, a worked out scheme was presented in 1960 where the new European University would be a two-year postgraduate residential institution for 500 students, teaching subjects of relevance to European integration. This would be accompanied by national research institutes which could access European funding and a structure for exchanges amongst existing institutions. But the lack of agreement endured, and this proposal was killed off at the Bonn summit of 1961 (Corbett 2005 p. 45). The idea remained sidelined for most of the decade until the Italians-who had now assumed responsibility for the university, thus distancing it from FrancoGerman wrangling - proposed a new institution be created in Italy. This came to fruition in 1969 when European leaders agreed to fund the European University Institute, a postgraduate and post-doctoral institute for teaching and research in the social sciences, in Florence, which opened in 1972 (Palayret 1996). However, this small, specialist institute wasn't the supranational university featuring the full range of subjects many had envisaged.

The debate remained dormant until 2005 when Commission President José Manuel Barroso proposed a European Institute of Technology which would undertake "high level education, research and innovation activities, both in some strategic thematic areas and in the field of science and innovation management" (Barroso 2006). The new institute, proposed to have a large campus in Strasbourg, was never created as it lacked sufficient backing from member states, existing universities and the businesses it was supposed to benefit (Meller 2006; Meller et al. 2006). The supranational university, therefore, remained the unfinished business of the European political project. The issue would go quiet until the election of pro-European Emmanuel Macron as French President in May 2017 who sought a complete overhaul of the European Union including tax convergence, reformed institutions, a joint EU budget and shared defence. Within this sweeping set of reforms, the sleeping idea of a European University would be reawakened. 


\section{From Idea to Implementation}

On the 26th September 2017, President Macron delivered a speech at the Sorbonne University, Paris, entitled New Initiative for Europe. The address sets out Macron's vision for a 'fair, protective and ambitious Europe' which stands in solidarity, united by the bonds that have always bound the European Union together: 'culture and knowledge'. The President argued that "fragmentation is only superficial' and that diversity is, in fact, our 'greatest opportunity". Macron used the example of the many languages of Europe which should be made an asset rather than being deplored, arguing that Europe should be a place where all students can speak at least two European languages by 2024. Moreover, instead of lamenting the divisions between nations, exchanges between them should be increased so by 2024 half of students "should have spent at least six months in another European country by the time they are 25 , whether they are university students or learning a trade". To realise this vision, the President proposed the creation of new structures in the European higher education landscape:

\footnotetext{
I believe we should create European Universities-a network of universities across Europe with programs that have all their students study abroad and take classes in at least two languages. These European Universities will also be drivers of educational innovation and the quest for excellence. We should set for ourselves the goal of creating at least 20 of them by 2024. However, we must begin setting up the first of these universities as early as the next academic year, with real European semesters and real European diplomas (Macron 2017).
}

Macron's Sorbonne speech was an influential driver of change, shaping the character of European higher education policy making in the coming months. This vision was embraced by the European Commission, who produced the report Strengthening European Identity through Education and Culture presented to EU Leaders at their meeting in Gothenburg on the 17th November 2017. The report placed at the heart of this agenda a renewed emphasis on the creation of a European Education Area "based on trust, mutual recognition, cooperation and exchange of best practices, mobility and growth", which should be in place by 2025 and would foster "a sense of a European identity and culture". Specifically, the report recommended "creating world-class European universities that can work seamlessly together across borders" (EU Commission 2017a).

The Commission also produced an accompanying document entitled Network of European Universities which considered actions for the next two years. This advocated a range of new initiatives aligned to Macron's speech, including establishing a School of European and Transnational Governance based on a network with partner institutions, development of further strategic partnerships between higher education institutions, creating 200 more Erasmus Mundus master's programmes, and increasing the visibility of the U-Multirank tool to promote the EU as an attractive study location. The report also set out potential initiatives with a 2025 perspective which included the creation of a European universities network "to reinforce and structure cooperation among higher education institutions". This would involve, first, the 
establishment of networks of universities and joint delivery of programmes with the use of distance learning tools, second new joint ventures and third the creation of institutions (EU Commission 2017b).

In December 2017, the European Council published the conclusions of the Gothenburg summit. These included a call for Member States, the Council and the Commission, in line with their respective competences, to take work forward with a view to:

strengthening strategic partnerships across the EU between higher education institutions and encouraging the emergence by 2024 of some twenty 'European Universities', consisting in bottom-up networks of universities across the EU which will enable students to obtain a degree by combining studies in several EU countries and contribute to the international competitiveness of European universities (EU Council 2017).

This position was then reaffirmed by the Education Committee of the Council who met on the 22nd May 2018. The Committee supported the emergence of 'European Universities', which they saw could play a flagship role in the creation of a European Education Area, as the main theme of the meeting (EU Council 2018).

With the political ground work within EU institutions complete, steps could now be taken to realise the new network. As a first step, to help conceptualise the new initiative, the Directorate-General for Education, Youth, Sport and Culture and the Directorate-General Joint Research Centre commissioned research to map out existing transnational collaborative partnerships, which captured forms of formal cooperation between higher education institutions from at least two European countries in the areas of education, research and/or innovation. The findings supported the argument that the new network would add value when compared to what currently exists. In particular, half of all respondents believed existing funding instruments-which are complex and require applications to multiple calls every year-are not suitable for deepening and extending transnational cooperation between higher education institutions. Furthermore, the study identified a number of administrative and legal issues - such as lack of common accreditation standards and differences in academic calendars - which prohibit more intense and sustainable cooperation. Here, we can note how the study identified specific issues that could be addressed with a European Statute to help achieve common EU-wide standards (Karvounaraki et al. 2018).

The next step involved refining and defining the new scheme which required developing selection criteria, following the procedures stipulated in the Erasmus+ Regulation, for a pilot phase and setting objectives. The pilot round was intended to test different innovative and structural models, while supporting the "creation of alliances, ideally composed of 5 to 8 partners". Two main objectives for the EUI were agreed:

1. Promoting common European values as enshrined in article 2 of the Treaty on European Union and a strengthened European identity by bringing together a new generation of Europeans, who are able to cooperate and work within different European and global cultures, in different languages, and across borders, sectors and academic disciplines. 
2. Reach a substantial leap in quality, performance, attractiveness and international competitiveness of European higher education institutions and contributing to the European knowledge economy, employment, culture and welfare by making best use of innovative pedagogies and striving to make the knowledge triangle a reality. 'European Universities' will be key drivers to boost the quality of higher education and where possible to strengthen its link to the research and innovation landscape in Europe and its outreach towards the society and economy (EU Commission 2018, p. 125).

Three 'key elements' were developed to indicate what was expected from successful alliances by 2025 . This included, first, a shared, integrated, long-term joint strategy for education with links to research and innovation and society at large; second, a European higher education inter-university 'campus', where all students and staff can move seamlessly (physically or virtually) between any of the partner institutions who have embedded mobility at all levels and deliver new joint and flexible curricula; third, European knowledge-creating teams of students, academics, and other parties of relevance to the alliances, to address societal and other challenges in a multi-disciplinary approach.

The call for the first round of pilot funding closed at the end of February 2019, and 54 applications for new alliances were received. The applications were initially reviewed by three experts and then considered by an evaluative committee who ranked the proposals. Those ranked the highest were selected, based on the funds available. The proposals were assessed against five criteria: relevance of the proposal, geographical balance, quality of the proposal and implementation, quality of the alliance cooperation arrangements, and sustainability and dissemination. From this process, 17 European Universities, involving 114 higher education institutions from 24 Member States (see Table 1), were selected and announced in June 2019 (EU Commission 2019). Each alliance of university networks will receive up to $€ 5 \mathrm{~m}$ over three years.

The second call opened in November 2019, similar to the first, the main difference being the initiative is now backed by more money, meaning there may be around 24 new alliances funded, rather than 17 in the first round. The results of the second round are expected in July 2020.

It is evident that the number of alliances after the second round will be far greater than the goal of 'at least 20' in Macron's Sorbonne speech. We can also see how this has produced a unique structure of alliances which can be described as a 'network of networks' - a series of self-contained, unique, alliances developed using a bottom-up approach, which are united through their membership of a top-down strategic scheme with common overarching aims and objectives. This is a novel organisational form for a university alliance, as it differs from established multilateral structures. 
Table 1 EUI alliances funded in the first pilot by university members and nation state

\begin{tabular}{|c|c|}
\hline \multicolumn{2}{|l|}{ UNA Europa - 1EUROPE } \\
\hline Alma Mater Studiorum - Universita di Bologna & Italy \\
\hline Freie Universitaet Berlin & Germany \\
\hline Katholieke Universiteit Leuven & Belguim \\
\hline The University of Edinburgh & United Kingdom \\
\hline Universidad Complutense de Madrid & Spain \\
\hline Universite Paris I Pantheon-Sorbonne & France \\
\hline Uniwersytet Jagiellonski & Poland \\
\hline \multicolumn{2}{|l|}{ The 4eu+ Alliance } \\
\hline Kobenhavns Universitet & Denmark \\
\hline Ruprecht-Karls-Universitaet Heidelberg & Germany \\
\hline Sorbonne Universite & France \\
\hline Universita degli Studi di Milano & Italy \\
\hline Univerzita Karlova & Czech Republic \\
\hline Uniwersytet Warszawski & Poland \\
\hline \multicolumn{2}{|c|}{ CHARM European University (Challenge-Driven, Accessible, Research-Based, Mobile)—CHARMEL } \\
\hline Eotvos Lorand Tudomanyegyetem & Hungary \\
\hline Trinity College Dublin & Ireland \\
\hline Universitat de Barcelona & Spain \\
\hline Universite de Montpellier & France \\
\hline Universiteit Utrecht & The Netherlands \\
\hline
\end{tabular}

\section{CIVICA - The European University In Social Sciences}

\begin{tabular}{l|l}
\hline European University Institute & Italy \\
Handelshogskolan I Stockholm & Sweden \\
Hertie School of Governance Mmeinnutzige Gmbh & Germany \\
Institut d' Études Politiques de Paris & France \\
Kozep-Europai Egyetem & Hungary \\
Scoala Nationala de Studii Politice Si & Romania \\
Administrative & \\
Universita Commerciale Luigi Bocconi & Italy \\
\hline CIVIS - A European Civic University Alliance & \\
\hline Eberhard Karls Universitaet Tuebingen & Germany \\
Ethniko Kai Kapodistriako Panepistimio Athinon & Greece \\
Stockholms Universitet & Sweden \\
Universidad Autonoma de Madrid & Spain \\
Universita degli Studi di Roma La Sapienza & Italy \\
Universitatea din Bucuresti & Romania \\
Universite d'Aix Marseille & France \\
Universite Libre de Bruxelles & Belguim \\
\hline
\end{tabular}

\section{CONEXUS_European University For Smart Urban Coastal Sustainability}

\begin{tabular}{l|l}
\hline Agricultural University of Athens & Greece \\
Fundacion Universidad Catolica de Valencia San & Spain \\
Vicente Martir & \\
\hline
\end{tabular}


Table 1 (continued)

\begin{tabular}{l|l}
\hline \multicolumn{1}{l}{$\begin{array}{l}\text { Klaipedos Universitetas } \\
\text { Sveuciliste U Zadru }\end{array}$} & Lithuania \\
Universitatea Tehnica de Constructii Bucuresti & Croatia \\
Universite de La Rochelle & Romania \\
ECIU University-ECIUn & France \\
\hline Aalborg Universitet & Denmark \\
Dublin City University & Ireland \\
Kauno Technologijos Universitetas & Lithuania \\
Linkopings Universitet & Sweden \\
Tampereen Korkeakoulusaatio Sr & Finland \\
Technische Universitat Hamburg & Germany \\
Universidade de Aveiro & Portugal \\
Universita degli Studi di Trento & Italy \\
Universitat Autonoma de Barcelona & Spain \\
Universiteit Twente & The Netherlands \\
Universitetet I Stavanger & Norway \\
\hline European digital UniverCity-EDUC & \\
\hline Masarykova Univerzita & Czech Republic \\
Pecsi Tudomanyegyetem & Hungary \\
Universita degli Studi di Cagliari & Italy \\
Universitaet Potsdam & Germany \\
Universite de Rennes I & France \\
Universite Paris Nanterre & France \\
\hline
\end{tabular}

European Partnership for an Innovative Campus Unifying Regions-EPICUR

Albert-Ludwigs-Universitaet Freiburg

Aristotelio Panepistimio Thessalonikis

Karlsruher Institut Fuer Technologie

Germany

Greece

Universitaet Fuer Bodenkultur Wien

Germany

Universite de Haute Alsace Uha

Austria

Universite de Strasbourg

France

France

Universiteit Van Amsterdam

The Netherlands

Uniwersytet Im. Adama Mickiewicza W Poznaniu Poland

\begin{tabular}{l|l}
\hline Alliance for Common Fine Arts Curriculum-EU4ART \\
\hline Accademia di Belle Arti di Roma & Italy \\
Hochschule Für Bildende Künste Dresden & Germany \\
Latvijas Makslas Akademija & Latvia \\
Magyar Kepzomuveszeti Egyetem & Hungary \\
\hline
\end{tabular}

European University Alliance for Global Health-EUGLOH

Communaute d'universites Et Etablissements

Universite Paris-Saclay

Ludwig-Maximilians-Universitaet Muenchen

France

Germany

(continued) 
Table 1 (continued)

\begin{tabular}{l|l}
\hline $\begin{array}{l}\text { Lunds Universitet } \\
\text { Szegedi Tudomanyegyetem }\end{array}$ & $\begin{array}{l}\text { Sweden } \\
\text { Hungary } \\
\text { Universidade do Porto }\end{array}$ \\
\hline European Universities Transforming to an Open, Inclusive Academy for 2050_EUTOPIA \\
\hline Goeteborgs Universitet & Sweden \\
The University of Warwick & United Kingdom \\
Universidad Pompeu Fabra & Spain \\
Universite de Cergy-Pontoise & France \\
Univerza V Ljubljani & Slovenia \\
Vrije Universiteit Brussel & Belguim \\
\hline
\end{tabular}

Fostering Outreach within European Regions, Transnational Higher Education and Mobility -FORTHEM

\begin{tabular}{|c|c|}
\hline Johannes Gutenberg-Universitat Mainz & Germany \\
\hline Jyvaskylan Yliopisto & Finland \\
\hline Latvijas Universitate & Latvia \\
\hline Universita degli Studi di Palermo & Italy \\
\hline Universitat de Valencia & Spain \\
\hline Universite dijon Bourgogne & France \\
\hline Uniwersytet Opolski & Poland \\
\hline \multicolumn{2}{|l|}{ The European University of the Seas-SEA-EU } \\
\hline Christian-Albrechts-Universitaet Zu Kiel & Germany \\
\hline Sveuciliste U Splitu & Croatia \\
\hline Universidad de Cadiz & Spain \\
\hline Universita Ta Malta & Malta \\
\hline Universite de Bretagne Occidentale & France \\
\hline Uniwersytet Gdanski & Poland \\
\hline \multicolumn{2}{|c|}{ University Network for Innovation, Technology and Engineering-UNITE! } \\
\hline Aalto Korkeakoulusaatio $\mathrm{Sr}$ & Finland \\
\hline Institut Polytechnique de Grenoble & France \\
\hline Kungliga Tekniska Hoegskolan & Sweden \\
\hline Politecnico di Torino & Italy \\
\hline Technische Universitat Darmstadt & Germany \\
\hline Universidade de Lisboa & Portugal \\
\hline Universitat Politecnica de Catalunya & Spain \\
\hline \multicolumn{2}{|c|}{ Young Universities for the Future of Europe-YUFE } \\
\hline Ita-Suomen Yliopisto & Finland \\
\hline Universidad Carlos Iii de Madrid & Spain \\
\hline Universita degli Studi di Roma Tor Vergata & Italy \\
\hline Universitaet Bremen & Germany \\
\hline Universiteit Antwerpen & Belgium \\
\hline Universiteit Maastricht & The Netherlands \\
\hline University of Cyprus & Cyprus \\
\hline University of Essex & United Kingdom \\
\hline
\end{tabular}




\section{Accounting for Success}

We can observe from the sequence of events set out above the EUI quickly gathered approval and moved to the implementation stage. This is an important milestone in European higher education policy history as in doing this the EUI overcame the political and practical obstacles of various schemes suggested over the preceding 70 years. For this reason, it is worth considering why the EUI succeeded where previous attempts at a supranational university failed. Here, a series of factors are presented to account for this breakthrough.

This first set of factors relate to the innovative 'network of networks' approach, which overcomes several obstructions all at once. First, it removes rivalry between nations as it locates the scheme and its beneficiaries in a wide range of locations without favouring one particular country. As Table 1 shows, the successful alliances include universities from a wide range of European states. Second, it eliminates disagreements over what form the institution should take as multiple forms of higher education can take place concurrently across different networks. One network, for example, can contain likeminded specialist institutions or those with a similar ranking, thus meaning the EUI overall creates multiple spaces for a wide range of universities. Third, it removes the expense of building a new physical campus and the difficulties of launching a new entity in a sector where history, esteem and status are paramount. Launching a new university isn't just expensive; it's also a high risk venture as institutions can take time to develop recognition and reputation. Fourth, it turns a threat into an opportunity. A new supranational university would be seen as a rival amongst not only existing universities but also nation states who have allocated considerable resources nurturing their own flagship universities. As Lehmann (2019) explains, one of the factors which inhibited the creation of a supranational university in earlier periods was the opposition from existing universities who saw it as a threat, particularly in the political battle for scarce resources. The EUI inverts this problem by creating a new source of funding which existing universities can bid for.

A second set of factors concern changes that have taken place in recent years within European universities - driven by the EU, nation states and universities themselvesthat have made realising the EUI more feasible. First, the Bologna Process has resulted in greater harmonisation across the continent, along with an improved understanding of the processes and organisation learning needed to achieve this. This includes harmonisation at the most elementary level, such as common terminology across countries as well as a shared understanding of the meaning and purpose of quality assurance. Moreover, Toderas and Stăvaru (2018) find participation in the European Higher Education Area (EHEA) results in 'spillover effects' across higher education systems, such as strengthening the culture of quality, increased use of deliberative policy-making instruments and the fostering of public accountability. The Bologna Process, therefore, produced structural changes which are conducive to the implementation of a new regional scheme such as the EUI. Second, as Maassen and Stensaker (2019) conclude, research-intensive universities have been changing their internal governance and organisational structures through "strengthening their 
organisational governance hierarchies", which "is often associated with increased professionalisation and specialisation with respect to managerial and administrative tasks and responsibilities". This leads to "tighter vertical steering and the emergence of more integrated organisations" which can respond to the "continuous need for flexibility and adaptivity". Universities are therefore now more like corporate entities driven by a strategic planning process which facilitates the implementation of new strategic schemes within institutions. This relates to the third factorinstitutional autonomy. As state oversight of higher education has moved away from traditional forms of 'command and control' towards new forms of public management (Paradeise et al. 2009; Dobbins and Knill 2014; Amaral et al. 2013; Krüger et al. 2018; De Coster et al. 2008), universities now have increased autonomy which frees them to invest, innovate and enter into alliance negotiations which they see as strategically beneficial. There is also a financial dimension to this argument as universities are expected to be more self-financing and be less dependent on direct state grants (De Dominicis et al. 2011; Stachowiak-Kudła \& Kudła 2017; Altbach et al. 2019 p. 74). As universities increasingly seek new streams of income, schemes such as the EUI are met with enormous enthusiasm as they provide new sources of funding to bid for. A fourth factor can be seen in the ascendancy of the internationalisation agenda across Europe (de Wit et al. 2015; Seeber and Lepori 2014) which has produced more outward-looking institutions that are more likely to collaborate with foreign partners. Moreover, European collaboration is now more established, following the activities of bodies such as the European Research Council. Fifth, the pursuit of national excellence schemes (Froumin and Lisyutkin 2015) and flagship universities (Gornitzka and Maassen 2017) in many European countries has not only produced a group of better-resourced institutions, but has also embedded the ideas of differentiation and stratification within higher education systems. This has fostered an environment where universities are strategically well placed (in terms of resources and status) to enter into alliances with similar counterparts.

\section{The Scope for Collaborative Advantage}

In 2011-12 Gunn and Mintrom embarked on a project which originated from the observations that university alliances were increasingly 'strategic', that in a period of increasing competition among universities collaboration represents a curious phenomenon, and that the behaviour of these alliances in the early 2010s appeared to match behaviour of private business in the first half of the 1990s. To provide a theoretical background which deals with these themes, the research drew upon the Art of Alliances, the seminal work by Rosabeth Moss Kanter (1994) which considers how partnerships can produce 'Collaborative Advantage'- the mutual benefit, or symbiotic advantage, yielded from the synergy of creating new value together. Applying this theory to higher education, a study was undertaken of three alliances - the Association of Pacific Rim Universities, Universitas 21, and the Worldwide Universities Network-which identified five factors which shape the ability of global university 
alliances to create collaborative advantage for their members. These are: (1) The alliance's strategic intent; (2) the comparative status of member universities; (3) the opportunities created for mutual learning among members; (4) the salience of the alliance inside member universities; and (5) the on-going relevance of the alliance and its capacity for change (Gunn and Mintrom 2013).

Guided by the first strand of Kanter's theory, which considers the attributes of effective alliances, we can see the EUI, by design, has the potential to generate collaborative advantage for its members. This is evident in how each alliance is not a short term deal but part of a long term process to deliver change over time, i.e., the alliances can be seen as 'living systems' which is indicative of longevity. The design of the EUI also places emphasis on each alliance addressing the challenges of achieving the expected transformational change by working together to jointly create new provision, i.e., they are about more than mere immediate exchange, which is a criterion for success. Moreover, each alliance has sufficient scope to shape their own internal infrastructures and linkages, i.e., they are not tightly controlled by a formal system. However, we should note each alliance will be different and some will be more effective than others.

The second strand of Kanter's theory considers how organisations seek out and select suitable partners. Here, the 'bottom-up approach' adopted allows groups of likeminded universities to freely collaborate and develop their own response to the call based on their local priorities. This means, at the level of each alliance, the universities involved are more likely to be compatible as they chose to work with each other. This matters as a degree of compatibility (similar specialism or strategic mission, comparable status or ranking, for example), including the less tangible aspects of compatibility (such as institutional values and cultures), is an important variable in determining harmony, longevity and success. At the aggregate level of the EUI, the creation of multiple alliances running concurrently creates separate spaces for collections of likeminded universities to cluster together. This diversity across all the alliances harnesses the power of very different types of institutions who are doing different things; this helps the overarching goals of the EUI to be achieved as its vision is being pursued in multiple ways.

We can also argue it could make the overall initiative more inclusive, as a broader range of institutions have a place where they can find compatible partners and contribute to the initiative. The extent to which this manifests itself in practice depends on the profile of institutions funded after the second round. Alternatively, the EUI may comprise of elite institutions, furthering the stratification of higher education in Europe. On this theme, Birk (2019), Director of the Erasmus+ National Agency for Higher Education at DAAD argues there may be a tension between inclusiveness and excellence, ${ }^{4}$ i.e., is the EUI for the elite big research universities or for all universities

\footnotetext{
${ }^{4}$ Birk finds Macron's Sorbonne speech supports both interpretations of the EUI, depending on if you read the German or the English translation. The sentence "Des universités européenes qui seront aussi des lieux d'innovation pédagogique, de recherche d'excellence" when translated into German became "Orte ... exzellenter Forschung" ("places of excellent research"), i.e., the EUI should be about excellence. The English translation was "drivers... of the quest for excellence", i.e., this is a quest which is open to being inclusive.
} 
who put forward a convincing case for intensified cooperation? And if it includes both, can it work? Moreover, this is set against the need to ensure all regions of Europe are included. Although some will advocate the need to concentrate resources in places of established excellence, Claeys-Kulik (2019), policy coordinator at the European University Association (EUA), urges European and national funders to be aware of the Matthew Effect ${ }^{5}$ and "find a balance between supporting such alliances and funding smaller scale collaboration projects that are in high demand under the current Erasmus+ programme". Claeys-Kulik (2019) warns "if too much funding was to be concentrated on a few alliances, this could hit resources in the higher education and research system as a whole" which would not help close the innovation gap within Europe.

The third dimension within The Art of Alliances addresses the different types of integration needed for a productive alliance. This draws our attention to what will perhaps be the greatest challenge for the new alliances as new approaches of integration will be needed to deliver transformational change. For example, a notable feature of the EUI is the 'embedded mobility' component, which the funding call describes as "a standard feature", where at "least $50 \%$ of the students within the alliance should benefit from such mobility, be it physical, virtual or blended." This target is highly ambitious and perhaps unprecedented. To involve over half of all students across a whole alliance is a much higher level of interaction than has hitherto been achieved through a bilateral or multilateral collaboration. In order to achieve this, many of the selected pilot alliances emphasise the use of virtual or blended forms of mobility as a means to meet the target. We can learn two things from this development. First it provides another example of how new forms of technology are reshaping higher education, in this instance, the mass mobility of students in the context of an alliance. This illustrates the use of digital technologies and virtual forms of integration in the modern academy. 'Virtual' mobility is also used by some to address concerns about the high volume of travel, and therefore large carbon footprint, produced by universities (Rumbley 2020). Second, it illustrates the growing relevance of 'Internationalisation at Home' $(\mathrm{IaH})$, a concept that first appeared twenty years ago, but has become more prominent in recent years (Robson et al. 2018). We can see how the EUI has the potential to be a driver of IaH through not just curriculum reform and the promotion of foreign language learning, but through bringing international experiences to the home campus through virtual means.

Another factor is the time needed to achieve the level of integration required to deliver results. A criticism that has been levelled at the EUI, which may limit the benefits derived from alliance membership, is that it is perhaps too ambitious for the prescribed timeframe. For example, a major challenge comes from the need to ensure the compatibility of curriculum and qualifications required for the credit and joint degrees to be awarded for time spent at other institutions within the alliance. This is a move that requires standardisation well beyond what has been achieved through the Bologna Process since 1999 and evokes many of the same difficulties (Sin et al.

\footnotetext{
${ }^{5}$ The Matthew Effect of accumulated advantage can be summarised by the adage "the rich get richer and the poor get poorer". The concept is applicable to matters of fame or status.
} 
2016; Yergebekov and Temirbekova 2012; Cippitani and Gatt 2009; Reichert 2010). This process may take time to implement and has triggered comments such as those from Sriram Pavan, President of the Erasmus Mundus Association, who spoke at the 2019 European Association for International Education conference in Helsinki:

With institutions having to overcome numerous legal and administration hurdles in each country, as well as quality assurance and credit recognition issues, three years would not be enough time to integrate processes ... Instead, institutions should be given at least seven years to forge meaningful links with each other (Pavan quoted in Grove 2019).

An issue related to the timeframes for establishing an alliance is whether the alliances funded as part of the EUI are completely new or established entities. Members of the Cesaer Network - the European association of leading specialised and comprehensive universities of science and technology-lobbied the European Commission, arguing that the second round of pilots should "put funding towards tried and tested institutional networks" and that "the results of the first call indicate that the European Commission is funding innovative approaches to higher education cooperation rather than already established and functioning models. In our view, the networks do not necessarily need to be new, but must demonstrate excellence, effectiveness and efficiency" (Cesaer 2019). Another argument that established networks may be more effective comes from Professor Eugenijus Valatka, Rector of Kaunas University of Technology, representing the ECIUn alliance which was successful in the first pilot round, who notes, concurring with the point above, that the EUI is a huge transformation, but then argues the ECUI network is capable of tackling these challenges, as the network isn't new but has a twenty-year history. Professor Valatka, speaking at an event held by the European Commission on the EUI on the 7th of November 2019 in Brussels, identifies a problem arising from the EUI pilots being expected to demonstrate a transformational ten-year vision within a three-year test period.

\section{Conclusion}

This chapter has explained how the EUI represents a unique approach to alliance formation in higher education described here as a 'network of networks'. In adopting this model, the EUI has overcome the difficulties that hampered various proposals to create a supranational university over the preceding 70 years. Moreover, the design of the EUI is congruent with the current climate in European higher education, making it appropriate for its time and place. The analysis presented here has considered how the new alliances have the potential to deliver collaborative advantage for their members. However, the EUI expects transformational change within a tight time frame. Moreover, this chapter only deals with the introduction of the EUI and the pilot phase, meaning the extent to which the EUI delivers its objectives remains to be seen. 
The launch of the EUI marks a new chapter in the evolving position of higher education in the European political project. If we accept the argument that the idea of a supranational university can be realised without the creation of a new physical campus, then we can now say the European University is much nearer a reality. The strong emphasis President Macron placed on European languages, identity and solidarity when inaugurating the initiative, which has been carried through into its design, illustrates how the EUI is primarily about European cultural integration. The French position on the European University has therefore aligned with the German position of 70 years earlier, where the EUI is placed to realise the original goals of the supranational university, albeit in a different form.

\section{References}

Altbach, P. G., Reisberg, L., \& Rumbley, L. E. (2019). Trends in Global Higher Education: Tracking an Academic Revolution. Rotterdam: UNESCO and Sense.

Amaral, A., Jones, G., \& Karseth, B. (Eds.). (2013). Governing Higher Education: National Perspectives on Institutional Governance, Vol. 2. Dordrecht: Springer.

Barroso, J. M. (2006).Speech: Europe: art or science? Opening Address $164^{\text {th }}$ Dies Celebration of Delft University of Technology, $13^{\text {th }}$ January. http://data.ellispub.com/pdf/EN/2006/Rapid/ SPEECH-06-5_EN.pdf

Beerkens, E. (2002). International inter-organisational arrangements in higher education: towards a typology. Tertiary Education \& Management, 8(4), 297-314.

Birk, K. (2019). European Universities: balancing excellence, exclusiveness and inclusion. EAIE blog. https://www.eaie.org/blog/european-universities-balancing-excellence-exclusivenessinclusion.html

Cesaer (2019). Position on European Universities. 28 th October 2019. https://www.cesaer.org/ content/5-operations/2019/20191028-position-on-european-universities.pdf

Cippitani, R., \& Gatt, S. (2009). Legal developments and problems of the Bologna Process within the European higher education area and European integration. Higher Education in Europe, 34(3-4), 385-397.

Claeys-Kulik, A. (2019). European Universities Initiative - Chances and Challenges. University World News, $6^{\text {th }}$ November 2019. https://www.universityworldnews.com/post.php? story $=20191106144804387$

Cole, A. (2010). Franco-German Europe. In Dyson, K. and Sepos, A. (Eds.) Which Europe? The Politics of Differentiated Integration (pp. 156-169). London: Palgrave Macmillan.

Corbett, A. (2005). Universities and the Europe of Knowledge: Ideas, institutions and policy entrepreneurship in European Union Higher Education Policy, 1955-2005. Basingstoke: Palgrave

Corbett, A. (2012). Principles, problems, politics... What does the historical record of EU cooperation in higher education tell the EHEA generation?. In Curaj, A., Scott, P., Vlasceanu, L., \& Wilson, L. (Eds.) European Higher Education at the Crossroads (pp. 39-57). Dordrecht: Springer.

De Coster, I., Forsthuber, B., Oberheidt, S., Parveva, T., \& Glass, A. (2008). Higher Education Governance in Europe: Policies, Structures, Funding and Academic Staff. Brussels: Eurydice. https:// op.europa.eu/en/publication-detail/-/publication/f4a537e6-0e90-413b-98b1-e9bf9b1eb90c

De Dominicis, L., Pérez, S. E., \& Fernández-Zubieta, A. (2011). European university funding and financial autonomy. A study on the degree of diversification of university budget and the share of competitive funding. Luxembourg: Publications Office of the European Union. https:// publications.jrc.ec.europa.eu/repository/handle/JRC63682 
de Wit, H., Hunter, F., Howard, L., \& Egron-Polak, E. (2015). Internationalisation of Higher Education Study. Brussels: Policy Department B Structural and Cohesion Policies, European Parliament. https://www.europarl.europa.eu/RegData/etudes/STUD/2015/540370/IPOL_ STU(2015)540370_EN.pdf

Dobbins, M., \& Knill, C. (2014). Higher education governance and policy change in Western Europe: International challenges to historical institutions. Dordrecht: Springer.

EU Commission (2017a). Strengthening European Identity through Education and Culture: The European Commission's contribution to the Leaders' meeting in Gothenburg, 17 November. https://ec.europa.eu/commission/sites/beta-political/files/communicationstrengthening-european-identity-education-culture_en.pdf

EU Commission (2017b). Strengthening European Identity through Education and Culture: The Commission's Contribution to the Leaders' Working Lunch Gothenburg, 17 November. https:// ec.europa.eu/commission/sites/beta-political/files/leaders-working-lunch-universities_en.pdf

EU Commission (2018). Erasmus + Programme Guide, Version 1 2019: 24-10-2018. https:// ec.europa.eu/programmes/erasmus-plus/sites/erasmusplus2/files/erasmus-plus-programmeguide-2019-version1_en.pdf

EU Commission (2019). First 17 "European Universities" selected: a major step towards building a European Education Area Brussels, Press release 26 June 2019. https://europa.eu/ newsroom/content/first-17-\%E2\%80\%9Ceuropean-universities\%E2\%80\%9D-selected-majorstep-towards-building-european-education_en

EU Council (2017). European Council meeting 14 December. https://www.consilium.europa.eu/ media/32204/14-final-conclusions-rev1-en.pdf

EU Council (2018). Draft Council conclusions on moving towards a vision of a European Education Area Brussels, 8 May. http://data.consilium.europa.eu/doc/document/ST-8701-2018-INIT/en/ pdf

Froumin, I., \& Lisyutkin, M. (2015). Excellence-driven policies and initiatives in the context of Bologna process: Rationale, design, implementation and outcomes. In Curaj, A., Matei, L., Pricopie, R., Salmi, J., \& Scott, P. (Eds.). The European higher education area: Between critical reflections and future policies. (pp. 249-265). Dordrecht: Springer.

Gornitzka, Å., \& Maassen, P. (2017). European Flagship universities: Autonomy and change. Higher Education Quarterly, 71(3), 231-238.

Grove, J. (2019). Defer Macron's dream for European universities, mobility experts say. Times Higher Education, $26^{\text {th }}$ September. https://www.timeshigh-ereducation.com/news/defermacrons-dream-european-universities-mobility-experts-say

Gunn, A., \& Mintrom, M. (2013). Global university alliances and the creation of collaborative advantage. Journal of Higher Education Policy and Management, 35(2), 179-192.

Hendriks, G., \& Morgan, A. (2001). The Franco-German Axis in European Integration. Cheltenham: Edward Elgar Publishing.

Kanter, R. M. (1994). Collaborative advantage: the art of alliances. Harvard Business Review, 72(4), 96-108.

Karvounaraki, A., Subramaniam, S., Hristov, H., Ojala, T., Jonkers, K., Huisman, J., Goenaga, X., (2018). Mapping of European transnational collaborative partnerships in higher education, EUR 29212 EN. Luxembourg: Publications Office of the European Union, ISBN 978-92-79-85302-9, https://doi.org/10.2760/560460, JRC111663.

Krüger, K., Parellada, M., Samoilovich, D., \& Sursock, A. (2018). Governance Reforms in European University Systems. Dordrecht: Springer.

Küsters, H. J. (1998). Walter Hallstein and the Negotiations on the Treaties of Rome 1955-57. In Loth, W., Wallace, W., \& Wessels, W. (Eds.). Walter Hallstein: The Forgotten European?. Basingstoke: Macmillan.

Lehmann, L. (2019). The controversy surrounding the idea of a European supranational university. In van Heumen, L., \& Roos, M. (Eds.). The Informal Construction of Europe. Abingdon: Routledge.

Maassen, P., \& Stensaker, B. (2019). From organised anarchy to de-coupled bureaucracy: The transformation of university organisation. Higher Education Quarterly, 73(4), 456-468. 
Macron, E. (2017). Speech on new initiative for Europe, 26 Septembre. Paris. https://www.elysee.fr/ emmanuel-macron/2017/09/26/president-macron-gives-speech-on-new-initiative-for-europe. en

Meller, P. (2006) Barroso hopeful for slimmer, cheaper European Institute of Technology. Science|Business Network $17^{\text {th }}$ October. https://sciencebusiness.net/news/73129/Barroso-hopefulfor-slimmer\%2C-cheaper-European-Institute-of-Technology

Meller, P., Hudson, R. L. and Lau, T. (2006) Barroso boost for European Institute of Technology. Science|Business Network, $1^{\text {st }}$ March. https://sciencebusiness.net/news/73914/Barroso-boostfor-European-Institute-of-Technology

Moodie, G. (2010) Associations of universities. In Peterson, P., Baker E., and McGaw, B. (Eds.) International Encyclopedia of Education, 3rd edition, (pp. 485-490). Oxford: Elsevier.

Orr, E., Unangst, L., \& de Wit, H. (2019) The long, problematic road towards a European University. University World News, (546) $6^{\text {th }}$ April. https://www.universityworldnews.com/post.php? story $=20190404102239861$

Palayret, J. M. (1996). A University for Europe: Prehistory of the European University Institute in Florence: (1948-1976), with Schreurs, R., Translated from French by Iain L. Fraser. Rome: Italian Presidency of the European Union. https://cadmus.eui.eu/handle/1814/36018

Paradeise, C., Reale, E., Bleiklie, I., \& Ferlie, E. (Eds.). (2009). University Governance. Dordrecht: Springer.

Pietsch, T. (2013). Out of Empire: The Universities' Bureau and the Congresses of the Universities of the British Empire, 1913-1939. In Schreuder, D. M. (Ed.). Universities for a new world: Making a global network in international higher education, 1913-2013. London: SAGE.

Reichert, S. (2010). The intended and unintended effects of the Bologna reforms. Higher Education Management and Policy, 22(1), 1-20.

Robson, S., Almeida, J., \& Schartner, A. (2018). Internationalization at home: time for review and development?. European Journal of Higher Education, 8(1), 19-35.

Rumbley. L. E. (2020). Internationalization of Higher Education and the Future of the Planet. International Higher Education, 100. 32-34.

Seeber, M., \& Lepori, B. (2014). The Internationalization of European higher education institutions. In Bonaccorsi, A. (Ed.). Knowledge, diversity and performance in European higher education: a changing landscape. Cheltenham: Edward Elgar Publishing.

Sin, C., Veiga, A., \& Amaral, A. (2016). Bologna Process Implementation Problems. In Sin, C., Veiga, A., \& Amaral, A. (Eds.). European policy implementation and higher education. Analysing the Bologna Process. (pp. 63-82). London: Palgrave Macmillan.

Stachowiak-Kudła, M., \& Kudła, J. (2017). Financial regulations and the diversification of funding sources in higher education institutions: selected European experiences. Studies in Higher Education, 42(9), 1718-1735.

Tadaki, M., \& Tremewan, C. (2013). Reimagining internationalization in higher education: international consortia as a transformative space?. Studies in Higher Education, 38(3), 367-387.

Toderas, N., \& Stăvaru, A. M. (2018). The Impact of the Bologna Process on the Governance of Higher Education Systems in Eastern Partnership Countries. In Curaj, A., Deca, L., \& Pricopie, R. (Eds.). European higher education area: The impact of past and future policies (pp. 707-721). Dordrecht: Springer.

Webber, D. (2005). Conclusion. in Webber, D. (Ed.), The Franco-German Relationship in the EU. London: Routledge.

Yergebekov, M., \& Temirbekova, Z. (2012). The Bologna process and problems in higher education system of Kazakhstan. Procedia-Social and Behavioral Sciences, 47, 1473-1478. 
Open Access This chapter is licensed under the terms of the Creative Commons Attribution 4.0 International License (http://creativecommons.org/licenses/by/4.0/), which permits use, sharing, adaptation, distribution and reproduction in any medium or format, as long as you give appropriate credit to the original author(s) and the source, provide a link to the Creative Commons license and indicate if changes were made.

The images or other third party material in this chapter are included in the chapter's Creative Commons license, unless indicated otherwise in a credit line to the material. If material is not included in the chapter's Creative Commons license and your intended use is not permitted by statutory regulation or exceeds the permitted use, you will need to obtain permission directly from the copyright holder.

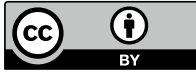

